\title{
Erythropoiesis: Development and Differentiation
}

\author{
Elaine Dzierzak and Sjaak Philipsen \\ Erasmus MC, Erasmus Stem Cell Institute, Department of Cell Biology, 3000 CA Rotterdam, The Netherlands \\ Correspondence: e.dzierzak@erasmusmc.nl
}

\begin{abstract}
Through their oxygen delivery function, red blood cells are pivotal to the healthy existence of all vertebrate organisms. These cells are required during all stages of life-embryonic, fetal, neonatal, adolescent, and adult. In the adult, red blood cells are the terminally differentiated end-product cells of a complex hierarchy of hematopoietic progenitors that become progressively restricted to the erythroid lineage. During this stepwise differentiation process, erythroid progenitors undergo enormous expansion, so as to fulfill the daily requirement of $\sim 2 \times 10^{11}$ new erythrocytes. How the erythroid lineage is made has been a topic of intense research over the last decades. Developmental studies show that there are two types of red blood cells-embryonic and adult. They develop from distinct hemogenic/ hematopoietic progenitors in different anatomical sites and show distinct genetic programs. This article highlights the developmental and differentiation events necessary in the produc-
\end{abstract} tion of hemoglobin-producing red blood cells.

\section{ONTOGENY OF THE HEMATOPOIETIC SYSTEM}

M icroscopic observations identified the first blood cells in the conceptus as those of the erythroid lineage. The early production of erythroid lineage cells occurs in the yolk sac, a transient extraembryonic tissue. These erythroid cells are nucleated and short-lived. They are derived from mesodermal cells that are formed from epiblast cells ingressing through the primitive streak (Lawson et al. 1991; Kinder et al. 1999). The newly formed mesodermal cells migrate posteriorly, enter the yolk sac, and come in close contact with endoderm cells (Fig. 1A). It is this interaction between the two cell layers that is required for the initiation of erythropoiesis (Belaoussoff et al. 1998). Interestingly, the mesodermal cells that migrate into the yolk sac form blood islands containing not only red blood cells, but also endothelial cells. The overlapping ontogenic appearance of both erythroid and endothelial cells indicates a common mesodermal precursor - the hemangioblast - with bilineage potential (Sabin 1920; Murray 1932). This is further supported by the overlap in genetic programs for the two lineages (i.e., expression of Flk-1 [KDR], Scl [Tal1], and CD34) and the lack of both lineages in embryos deficient for some of these genes (Shalaby et al. 1995; Tavian et al. 1999; Park et al. 2005). Surprisingly, hemangioblasts in vivo are localized not in the yolk sac but in the posterior primitive streak (Huber et al. 2004). As they migrate to the yolk sac, they begin their commitment to endothelial and hematopoietic progenitors, with several of these cells contributing to the formation of each blood island (Ueno and Weissman

Editors: David Weatherall, Alan N. Schechter, and David G. Nathan

Additional Perspectives on Hemoglobin and Its Diseases available at www.perspectivesinmedicine.org

Copyright (C) 2013 Cold Spring Harbor Laboratory Press; all rights reserved; doi: 10.1101/cshperspect.a011601

Cite this article as Cold Spring Harb Perspect Med 2013;3:a011601 
A

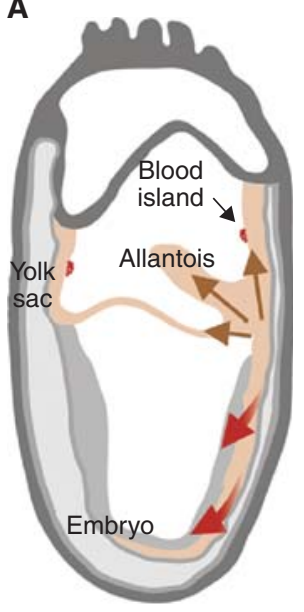

C

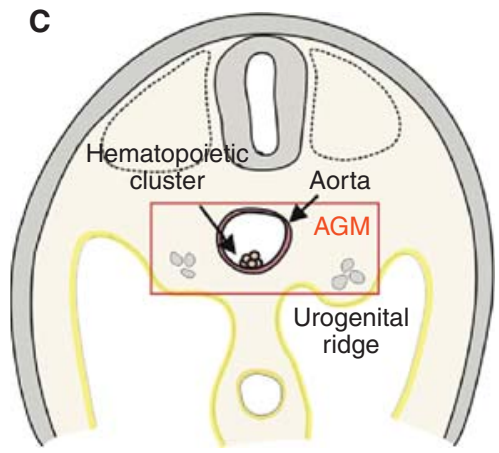

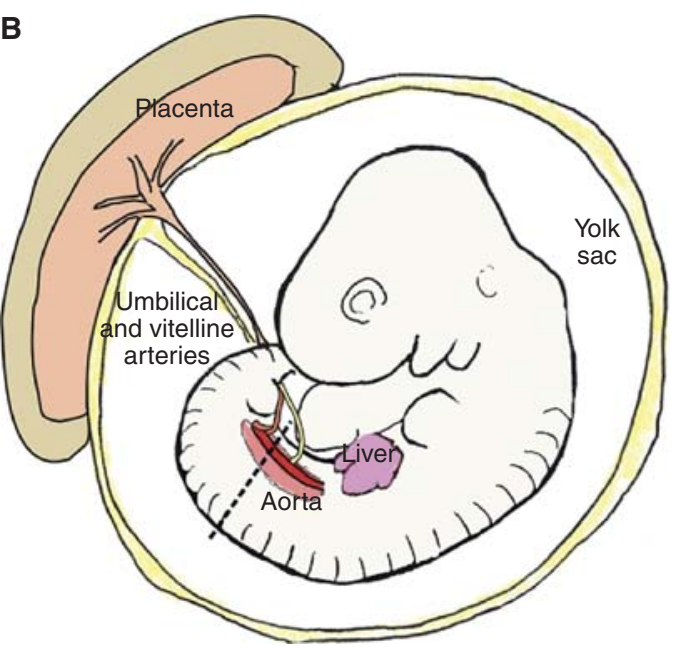

B

D

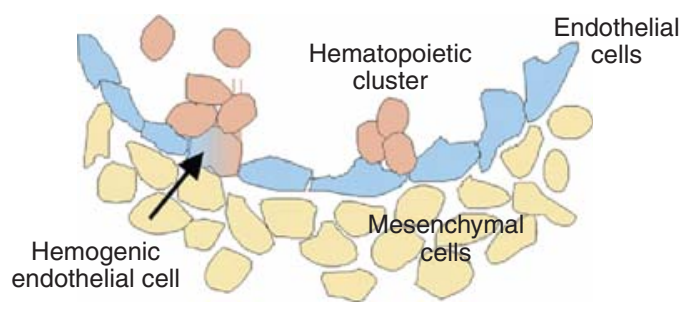

Figure 1. Ontogeny of the mouse hematopoietic system. (A) During gastrulation of the mouse conceptus, emerging mesodermal cells (brown arrows) migrate to the extraembryonic compartments (yolk sac and allantois). Blood islands begin to form in the yolk sac upon interactions of the mesoderm (orange) with the endoderm (gray). (Red arrows) Mesoderm migrating into the embryo proper. (B) Embryonic day 10.5 (E10.5) mouse embryo. Hematopoietic sites include the aorta (AGM region), yolk sac, umbilical and vitelline arteries, placenta, and liver. (Dotted line) The transverse section in panel C. (C) Transverse section showing the AGM region of an E10.5 mouse embryo. Urogenital ridges are lateral to the aorta. A hematopoietic cluster on the ventral wall of the aorta is shown. (D) Close-up of the aorta showing a hemogenic endothelial cell transitioning to a hematopoietic cluster cell. Nonhemogenic endothelial cells (blue) and mesenchymal cell (yellow) are shown.

2006). Yolk sac blood islands containing primitive erythrocytes are detectable in the mouse conceptus at embryonic day 7.5 (E7.5) (Russell and Bernstein 1966) and in the human conceptus at $\sim 16-20 \mathrm{~d}$ of gestation (Tavian and Peault 2005).

In contrast to the rapid commitment and differentiation of primitive erythroid cells from migrating mesodermal cells, the adult erythroid lineage takes its origin from a more complex cell lineage differentiation hierarchy, with hemato- poietic stem cells (HSCs) as the founder cells for this hierarchy. A cohort of rare HSCs is harbored in the bone marrow and continuously replenishes the blood system throughout adult life. To produce adult red blood cells and the many other functionally distinct lineages of differentiated blood cells, such as lymphocytes, macrophages, granulocytes, and megakaryocytes, HSCs undergo a relatively long and extensive process of cellular differentiation and proliferation. In the mouse embryos, HSCs appear $3 \mathrm{~d}$ later in 
ontogeny than yolk sac blood islands (Muller et al. 1994; Medvinsky and Dzierzak 1996). This late appearance suggests an independent mesodermal origin for HSCs. How the adult HSC-based hierarchy develops in the embryo, and from what precursors HSCs are derived, is an important focus of developmental studies.

Again, the first clues on HSC development came from microscopic observations of a variety of developing vertebrate embryos (amphibian, avian, and mammalian). Clusters of hematopoietic cells were found within the embryo in the aorta-gonad-mesonephros (AGM) region, closely associated with the ventral lumenal aspect of the aorta (Fig. 1B-D) (for review, see Dzierzak and Speck 2008). The results of avian embryo grafting experiments performed in the mid-1970s (Dieterlen-Lievre 1975; Martin et al. 1978; Beaupain et al. 1979; DieterlenLievre and Martin 1981) suggested that the development of the adult hematopoietic system begins with these clusters. Grafts of quail embryo bodies onto chick yolk sacs before vascularization revealed that the adult blood system of the chimera was quail-derived. Moreover, the embryonic aorta was found to contain hematopoietic progenitors (Cormier and DieterlenLievre 1988), suggesting that this vessel is responsible for the generation of adult hematopoietic cells. Similarly, lineage-tracing experiments, in which individual blastomeres of the 32-cell stage Xenopus embryo were marked, showed that the blastomeres contributing to the formation of the ventral blood islands (yolk sac) are distinct from the blastomeres that contribute to the formation of the aorta, hematopoietic clusters, and pronephros (CiauUitz et al. 2000). Thus, the specific localization of intrabody hematopoiesis in frog embryos has been found to be associated with the dorsal aorta and pronephros region (Turpen and Knudson 1982). These nonmammalian vertebrate embryo studies concluded that the first emergence of hematopoietic cells is in the extraembryonic yolk sac; the subsequent emergence of hematopoietic cells occurs both extraembryonically and intraembryonically; and the permanent contributors to the adult hematopoietic system are intraembryonically derived hemato-
Erythropoiesis: Development and Differentiation

poietic cells, with most extraembryonic hematopoietic cells becoming extinct. Importantly, the close association of hematopoietic cell clusters and endothelial cells on the ventral aspect of the aorta (Dieterlen-Lievre 1975) led to the hypothesis that the late-emerging, permanent adult hematopoietic system is derived from specialized "hemogenic" endothelial cells (Fig. 1D).

In contrast to the nonmammalian vertebrate species, the origin of the first HSCs in mammalian embryos was uncertain and, until the 1990s, thought to be the yolk sac (Moore and Metcalf 1970). Cell tracing studies of early stage mammalian embryos required experimental approaches different from the grafting approaches (which rely on ex utero development and large embryo size) taken in avian and amphibian embryos. One approach includes the stringent functional test for HSCs in different regions of the early/midgestation mouse conceptus - the in vivo transplantation of such cells into adult irradiated recipients. Much like adult bone marrow cell transplantations, long-term high-level self-renewing hematopoietic repopulation of adult recipients reveals the presence of HSCs in the injected cell population. Transplantation of cells from several embryonic hematopoietic tissues (yolk sac, intraembryonic AGM region, chorio-allantoic placenta, liver) showed that the first tissue to contain HSCs was the AGM (Fig. 1B,C) (Muller et al. 1994; Gekas et al. 2005; Ottersbach and Dzierzak 2005). HSCs were further localized to the aorta, vitelline, and umbilical arteries at E10.5 (de Bruijn et al. 2000). Moreover, organ explant cultures showed that the AGM region de novo produces the first adult type HSCs (Medvinsky and Dzierzak 1996). One to 1.5 d later, the mouse yolk sac, placenta, and liver also contain HSCs. Because the vascular connection between the embryo body and the extraembryonic hematopoietic sites occurs at E8.25 (Downs 1998) and the circulation carries cells between these sites, the origin of the HSCs found in these other tissues remains unknown.

The presence of hematopoietic clusters in the mouse aorta and vitelline/umbilical arteries at the time of HSC generation is intriguing (Fig. 1D). Functional studies have shown that 


\section{E. Dzierzak and S. Philipsen}

AGM HSCs express the same molecules (Wood et al. 1997; de Bruijn et al. 2002; North et al. 2002) as aortic hematopoietic cluster cells and, in some cases, aortic endothelial cells. Genetic (conditional knockout) studies of the Runxl transcription factor (Chen et al. 2009) show an endothelial cell requirement for this factor in the generation of HSCs and vascular clusters, suggesting that HSCs are generated from functioning vascular endothelial cells that retain hematopoietic potential. Recent live imaging of the midgestation mouse aorta has confirmed this, clearly showing in real time the endothelial-to-hematopoietic cell transition (Boisset et al. 2010). The emerging cells are rare, localized to the ventral aspect of the aorta, and begin to express all of the expected HSC markers as they transit from a flat endothelial to a round hematopoietic morphology (Boisset et al. 2010; Yokomizo et al. 2012). Thus, HSCs are derived from endothelial cells.

With the focus on hemoglobin-producing erythrocytes — primitive erythrocytes generated early in the yolk sac and adult erythrocytes from vascular endothelial-derived HSCs-there are intermediate types of hematopoietic progenitors also generated in the embryo (Fig. 2). Before HSCs are generated at E10.5, definitive erythro-myeloid progenitors are found in the E8.5/E9 yolk sac and placenta (Alvarez-Silva et al. 2003; McGrath and Palis 2005), and multipotent (erythroid-myeloid-lymphoid) hematopoietic progenitors (Godin et al. 1995) are found in the E9 AGM, most likely in hematopoietic clusters. Tissue explant culture before progenitor assay reveals that already by E8 the

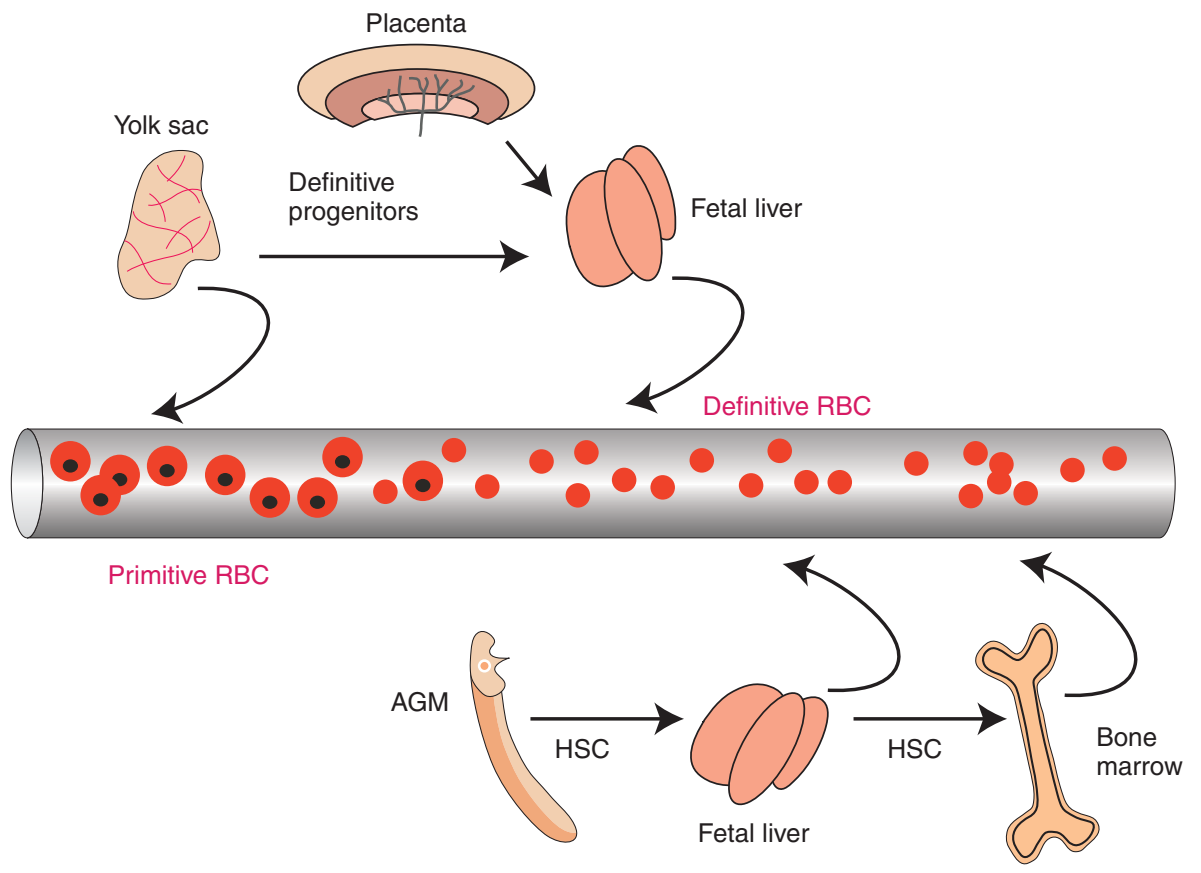

Figure 2. Ontogeny of erythroid lineage cells in the circulation. Embryonic erythrocytes (primitive red blood cells $[\mathrm{RBCs}]$ ) are made by the yolk sac at E7.5 and are found in the circulation until $\sim \mathrm{E} 11 / 12$. At E9, the yolk sac and placenta generate definitive progenitors that migrate to the fetal liver, where they differentiate to definitive RBCs (expressing fetal/adult globin) and enter the circulation. At E10.5, the AGM generates the first HSCs that migrate to the fetal liver and differentiate to the erythroid lineage (among other lineages), and these definitive RBCs enter the circulation. Fetal liver HSCs migrate and colonize the bone marrow at birth, where they provide lifelong production of definitive RBCs for the circulation. The spleen also is a site of differentiation for erythroid cells (not shown). 
yolk sac, AGM, and allantois (Cumano et al. 1996; Zeigler et al. 2006; Corbel et al. 2007) contain cells with hemogenic potential. Interestingly, in the absence of circulation in $N c x 1^{-1-}$ embryos (heartbeat defect), the numbers of erythro-myeloid progenitors in the yolk sac were found to be equivalent to the cumulative number of progenitors in wild-type embryos in all anatomic sites (Lux et al. 2007). No progenitors were found in the $N c x 1^{-/-} \mathrm{AGM}$, suggesting that the yolk sac normally generates all of these progenitors and distributes them to other tissues. As the cells colonize the liver, the newly emigrated progenitors expand and differentiate toward the definitive erythroid lineage (Ema and Nakauchi 2000).

\section{ERYTHROID LINEAGE DIFFERENTIATION DURING ONTOGENY}

Primitive erythrocytes, emerging in the extraembryonic yolk sac, are relatively large cells. The primitive cells are characterized by the expression of embryonic globins ( $\varepsilon y, \beta h 1$, and $\zeta$ in the mouse; $\varepsilon, \gamma$, and $\zeta$ in man), which form a variety of distinguishable hemoglobin tetramers in man $\left(\zeta_{2} \varepsilon_{2}\right.$ [Gower1], $\alpha_{2} \varepsilon_{2}$ [Gower2], $\zeta_{2} \gamma_{2}$ [Portland1], $\zeta_{2} \beta_{2}$ [Portland2]). In mammals, these are the only erythroid cells that retain their nucleus when they enter the circulation. Once released in the bloodstream, the macrocytic primitive erythrocytes retain proliferative capacity, and mitotic figures are observed in the circulating blood of early mammalian embryos (Lin et al. 1996). Intravascular erythropoiesis is not normally observed at any other developmental stage. The long-held view that primitive erythrocytes remain nucleated and that they disappear from the circulation very quickly during the embryonic-to-fetal transition period has been recently revised. In fact, primitive cells enucleate very efficiently between E12.5 and E14.5, resulting in macrocytic, enucleated erythrocytes (Fraser et al. 2007). Beginning at E11.5, newly emigrating erythro-myeloid progenitors (and subsequently HSCs) differentiate in the fetal liver to produce the first definitive erythrocytes (Fig. 2). There is an immediate switch to fetal/adult globins when definitive
Erythropoiesis: Development and Differentiation

erythropoiesis starts in the fetal liver. Expression of a specific fetal $\beta$-like globin ( $\gamma$-globin) is a feature of anthropoid primates. Hemoglobin tetramers consisting of $\alpha$ - and $\gamma$-globin chains $\left(\alpha_{2} \gamma_{2}\right)$ are known as $\mathrm{HbF}$ in humans. These hemoglobins allow the developing fetus to extract oxygen more efficiently from the maternal blood. Mammalian definitive erythrocytes expel their nucleus before they enter the circulation and are smaller in size than primitive erythrocytes.

Around the time of birth, the site of erythropoiesis switches to the bone marrow and the spleen. Humans rely mainly on the bone marrow for steady-state adult erythropoiesis, but in mice the spleen remains an important erythropoietic organ during adult life. Under erythroid stress conditions, for example, low oxygen pressure or anemia, the spleen of both mouse and man is used to expand the erythropoietic capacity (Socolovsky 2007).

Fetal globin expression is silenced in adult erythropoiesis. Hemoglobin tetramers composed of $\alpha$ - and $\beta$-globin $\left(\alpha_{2} \beta_{2}\right.$, HbA1 $)$ account for $\sim 97 \%$ of all hemoglobin in adult erythrocytes. $\mathrm{HbA} 2\left(\alpha_{2} \delta_{2}\right)$ and $\mathrm{HbF}$ account, respectively, for $\sim 2 \%$ and $\sim 1 \%$ of total hemoglobin in most adults. High $\mathrm{HbF}$ is restricted to a few cells, termed $\mathrm{F}$ cells, in normal adults (Boyer et al. 1975). Clonal analysis has shown that $\mathrm{F}$ cells are derived from the same progenitor cells as the cells containing adult globin, ruling out that fetal and adult stem cell lineages coexist (Papayannopoulou et al. 1977). Some individuals maintain higher levels of $\mathrm{HbF}$ throughout adult life. This condition, known as hereditary persistence of fetal hemoglobin (HPFH), is caused in the majority of cases by deletions in the $\beta$-globin locus, but also by point mutations in the $\gamma$-globin gene promoters (Stamatoyannopoulos 2005). In rare cases, the HPFH phenotype does not segregate with the $\beta$-globin locus, suggesting a trans-regulatory mechanism (see also Sankaran and Orkin 2013). The HPFH condition is not clinically manifest, but it is a factor ameliorating the effects of $\beta$-thalassemia and sickle cell disease. Reactivation of $\gamma$-globin expression in adults with these disorders is therefore a very attractive therapeutic approach, 
because the large majority of patients will have normal $\gamma$-globin genes that they have switched off after birth. Despite the fact that mice do not have a fetal $\beta$-like globin gene, the $\gamma$-globin genes in human $\beta$-globin locus transgenes are expressed in the early fetal liver and silenced subsequently in development between E13.5 and E14.5 (Dillon and Grosveld 1991; Strouboulis et al. 1992). Furthermore, $\gamma$-globin transgenes with HPFH mutations in the promoter phenocopy the HPFH condition in mice (Berry et al. 1992; Peterson et al. 1995).

\section{ERYTHROID DIFFERENTIATION WITHIN THE ADULT HEMATOPOIETIC HIERARCHY}

Erythroid cells are derived from HSCs, but the differentiation path they follow is still a matter of debate (Fig. 3) (Buza-Vidas et al. 2007). Immature progenitors are capable of giving rise to multilineage colonies, but whether there is a fixed order to cell fate decisions (i.e., at each stage a cell has limited choices) or whether there is greater plasticity to a cell's potential fates remains to be resolved. The classical model, put forward by the Weissman group, posits a decision between two fates at each step in differentiation, thereby gradually diminishing lineage potential (Fig. 3). More recently, an alternative scheme proposed by Adolfsson et al. (2005) identified a highly proliferative lymphoidprimed multipotent progenitor (LMPP) with GM potential but devoid of the ability to adopt erythroid or megakaryocytic lineage fates (Fig. 3, dotted arrows).

Cell populations corresponding to these progenitors can be purified by flow cytometric sorting based on the expression of various cell surface markers. Lineage output of these cells is determined by the mature differentiated cells emerging in colony assays in response to growth factors. Immature erythroid-restricted progenitors are identified as the burst forming uniterythroid (BFU-E), so-called because its earliest progeny are motile, giving rise to a multi-subunit colony (or burst). These large colonies containing up to several thousand hemoglobinized cells appear after 5-8 d (mouse) or 10$14 \mathrm{~d}$ (human) in methylcellulose cultures. Their growth is dependent on several factors, the most important of which are stem cell factor (SCF), thrombopoietin (TPO), interleukin 3 (IL3), IL11, and FLT3-ligand. BFU-E occurs at a frequency of $40-120 / 10^{5}$ bone marrow cells and also circulates in the peripheral blood at a frequency of $10-40 / 10^{5}$ light-density mononuclear cells (Migliaccio et al. 2001).

More mature erythroid progenitors, colonyforming units-erythroid (CFU-E), consist of small colonies of 16-125 cells that appear after $2-3 \mathrm{~d}$ (mouse) or 5-8 d (human) in methylcellulose culture. They are fivefold to eightfold more abundant than BFU-E in bone marrow and under normal circumstances do not appear in the circulation. As progenitors undergo the differentiation process, their numbers increase, with their proliferative potential simultaneously decreasing.

Several techniques have been described for the production of erythroblasts in liquid cultures (Fibach et al. 1989; Dolznig et al. 2001; Migliaccio et al. 2002). Although culture conditions differ in each protocol, SCF, erythropoietin (EPO), dexamethasone (Dex), and transferrin are commonly present, usually supplemented by insulin or IGF-1. In adult peripheral blood, the majority of the in vitro erythroid expansion potential resides in CD34- ${ }^{-}$cells (van den Akker et al. 2010). These liquid cultures are advantageous for producing large numbers of erythroblasts from peripheral blood samples, thus enabling functional analyses of normal or abnormal erythropoiesis without the need for bone marrow sampling. In addition, erythroid cultures can also be obtained using mouse or human embryonic stem cells as the starting material (Carotta et al. 2004; Pilat et al. 2005; Olivier et al. 2006), and large-scale production of fully matured human erythrocytes has been reported (Neildez-Nguyen et al. 2002; Giarratana et al. 2005). The advent of induced pluripotent stem (iPS) cells raises prospects for production of patient-specific erythrocytes for transfusion purposes. However, at present, it is prohibitively expensive and a daunting task to generate the vast numbers of cells required for clinical practice (Douay and Andreu 2007; see also Arora and Daley 2012). 


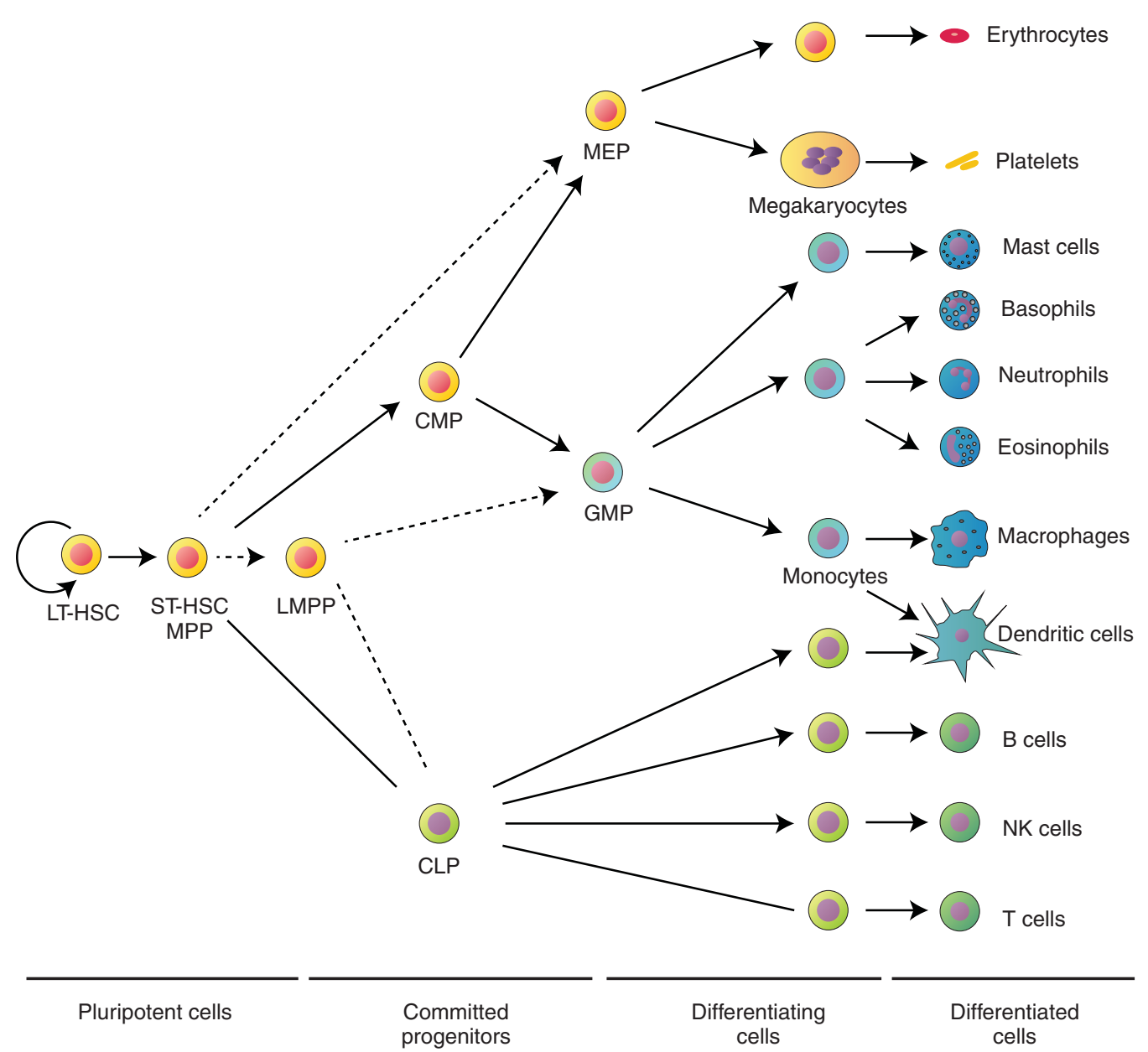

Figure 3. Proposed models for the hematopoietic hierarchy. In the model proposed by the Weissman group (Kondo et al. 1997; Akashi et al. 2000; Manz et al. 2002) (solid arrows), multipotential progenitors (MPPs or short-term HSCs [ST-HSCs]) give rise to either a common lymphocyte progenitor (CLP) or a common myeloid progenitor (CMP), which, in turn, gives rise to either a granulocyte-macrophage progenitor (GMP, equivalent to CFU-GM) or a megakaryocyte-erythroid progenitor (MEP). The alternate model suggested by the Jacobson group (Adolfsson et al. 2005) (dotted arrows) involves the generation of MEPs directly from the MPPs/STHSCs, whereas a lymphoid-primed multipotential progenitor (LMPP) has the potential to generate both CLPs and GMPs. LT-HSC, Long-term hematopoietic stem cell; NK cell, natural killer cell. (This figure is modified from data by Ferreira et al. 2005; reprinted, with permission, from the author as defined by the American Society for Microbiology.)

\section{ERYTHROPOIESIS: REGULATION AND NICHE}

Erythrocytes represent the most common cell type in adult blood. Human blood contains $\sim 5 \times 10^{6}$ erythrocytes per microliter (normal range $4.7 \times 10^{6}$ to $6.1 \times 10^{6}$ for males and 4.2 $\times 10^{6}$ to $5.4 \times 10^{6}$ for females); these cells have an average life span of $120 \mathrm{~d}$. New erythrocytes are constantly produced in the bone marrow, which provides a niche consisting of endothelial cells of the vascular system, osteoblasts, stromal cells, hematopoietic cells, and the extracellular matrix. This complex niche supports direct cell-cell contact and exposure of the developing hematopoietic cells to cell adhesion molecules, 
growth factors, and cytokines. The earliest erythroid progenitors are responsive to cytokines including TPO, GM-CSF, IL3, and IL11, and in particular to SCF. SCF binds to its receptor KIT, a tyrosine kinase that signals through several pathways including PI-3 kinase, Src kinases, and PLC- $\gamma$. At subsequent stages, SCF acts synergistically with EPO in the proliferation and expansion of the developing erythroid progenitors and may play a role in phosphorylating the EPO receptor itself ( $\mathrm{Wu}$ et al. 1995; see Bunn 2013). Erythroid cells at the terminal stages of differentiation have shed their nucleus, endoplasmic reticulum, and mitochondria, and, consequently, they are no longer able to proliferate. To maintain the red blood cell count in the $\sim 5$ Lofblood of an adult individual, $\sim 2.4$ $\times 10^{6}$ new erythrocytes have to be produced each second. The new cells enter the circulation as reticulocytes that are still engaged in protein translation. In humans, it takes $\sim 1 \mathrm{wk}$ for reticulocytes to complete the maturation process. In the bone marrow, a series of intermediate erythroid precursors can be recognized that progressively gains erythroid characteristics (Fig. 4). Development from the pro-erythroblast to the reticulocyte involves four to five rapid cell divisions, resulting in a progressive reduction in cell size. Mature erythrocytes have a diameter of only $6-8 \mu \mathrm{m}$. Their small size and biconcave shape creates a large surface area for gas ex- change and allows the cells to enter the microcapillaries in the tissues.

Under steady-state conditions, $\sim 1 \%$ of the erythrocytes are cleared every day and replaced by new cells. Remarkably, the rate of erythropoiesis can increase significantly from this baseline level in response to hypoxic stress, which occurs when adequate oxygen supply to all tissues is compromised by insufficient numbers of functional erythrocytes. Increasing red cell production is the primary response to counteract hypoxic stress. EPO production in the kidneys is directly regulated by tissue oxygen tension through the activity of the hypoxia-inducible transcription factor complex. Although EPO is the main regulator of red cell production (see Bunn 2013), other factors have an auxiliary role in the expansion of the erythroid progenitor compartment through their support of progenitor self-renewal. In particular, bone morphogenetic protein 4 (BMP4)/SMAD5 (Lenox et al. 2005), STAT5 (Socolovsky et al. 2001), SCF/KIT (Menon et al. 2006), and the glucocorticoid receptor (GR) (Bauer et al. 1999) are known to be involved.

A decreased apoptotic rate of erythroid progenitors may also contribute to the increase in red cell production that occurs under erythropoietic stress. It is believed that under steadystate conditions up to $60 \%$ of pro-erythroblasts succumb to apoptosis in the mouse spleen (Liu

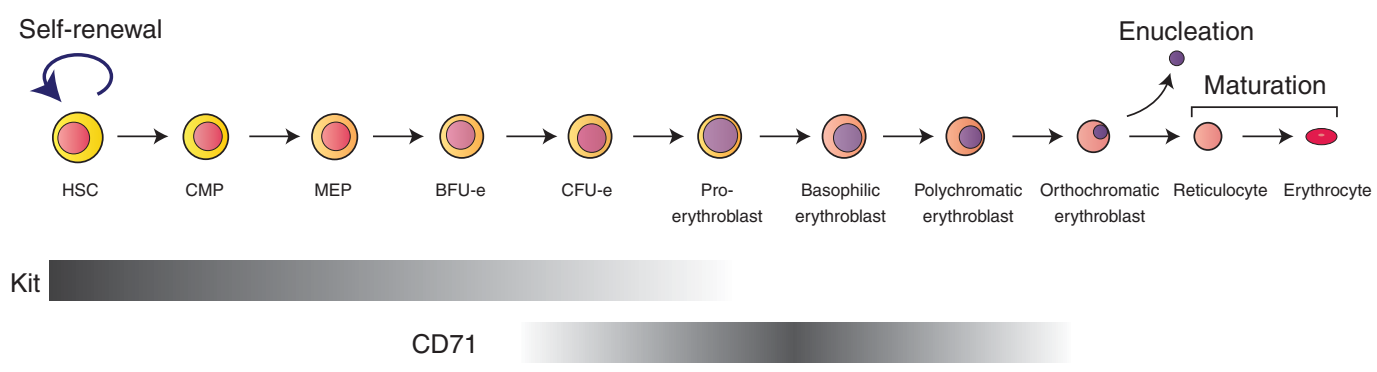

Ter119/GPA

Figure 4. Erythroid differentiation in the mouse. The expression of the most commonly used cell surface markers to identify the various stages is indicated by the bars. Cells at the CFU-e and pro-erythroblast stage are the most sensitive to, and dependent on, the presence of EPO. Gray, low expression; black, high expression; HSC, hematopoietic stem cell; CMP, common myeloid progenitor; MEP, megakaryocyte-erythroid progenitor; BFU-e, burst-forming unit, erythroid; CFU-e, colony-forming unit, erythroid. 
et al. 2006). Mice deficient for the STAT5 transcription factor, the major downstream signaling target of EPOR, have a blunted stress erythropoietic response. The erythroid progenitors have an increased rate of apoptosis attributed to their failure to up-regulate expression of the antiapopotic BCL-X $\mathrm{L}$ protein (Socolovsky et al. 1999, 2001). Furthermore, the FAS/FASL death receptor/death ligand system has been proposed to regulate erythroid homeostasis (De Maria et al. 1999). Under stress conditions, expression of FAS and FASL is reduced in erythroid cells and could contribute to the enhanced survival of these cells, further indicating that the survival function of the EPOR/STAT5 pathway is an important modulator of the erythropoietic rate (Liu et al. 2006).

\section{ERYTHROBLASTIC ISLANDS ARE STRUCTURAL UNITS OF TERMINAL ERYTHROID DIFFERENTIATION}

The erythroblastic island is a structural unit in the bone marrow where terminal erythroid differentiation takes place (Bessis 1958). It consists of a central macrophage (also known as the nurse cell) surrounded by differentiating erythroid progenitors (Fig. 5). Erythroblastic islands are also found in the mouse fetal liver (Fig. 5), but a role for an analogous structure has not been identified in the yolk sac. The fact that yolk sac cells enter the circulation without un-
Erythropoiesis: Development and Differentiation

dergoing enucleation, a process in which the macrophage plays an important role, supports the notion that primitive erythropoiesis does not require the formation of islands. However, macrophages are formed during primitive hematopoiesis, and further investigations are necessary to determine the role of these cells in primitive erythropoiesis.

Several proteins on the surface of the macrophage and the erythroblasts mediate interactions between the macrophage and erythroblasts, and between the erythroblasts themselves. The erythroblast-macrophage protein (EMP or macrophage-erythroblast attacher MAEA) is expressed on both cell types and mediates adhesion between the cells. MAEA knockout mice survive until birth, displaying defects in terminal erythroid maturation (Soni et al. 2006). Formation of erythroblastic islands is impaired and MAEAnull macrophages appear to lack the extensive cytoplasmatic extensions typical of mature macrophages. MAEA-null macrophages are unable to interact with wild-type erythroblasts. In contrast, MAEA-null erythroblasts can interact with wild-type macrophages, but this does not rescue the enucleation defect of these erythroblasts. In enucleating wild-type erythroblasts, MAEA colocalizes with F-actin aggregates present at the constriction between the extruding nucleus and the reticulocyte. The actin cytoskeleton in MAEA-null erythroblasts is predominantly localized to the cell membrane,
A

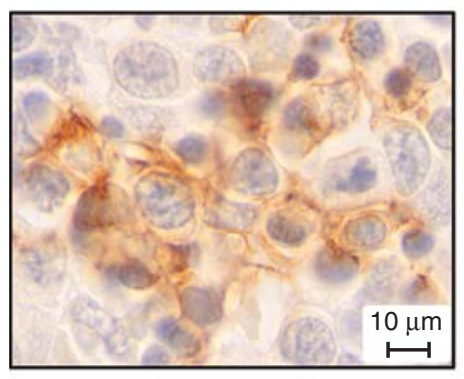

B

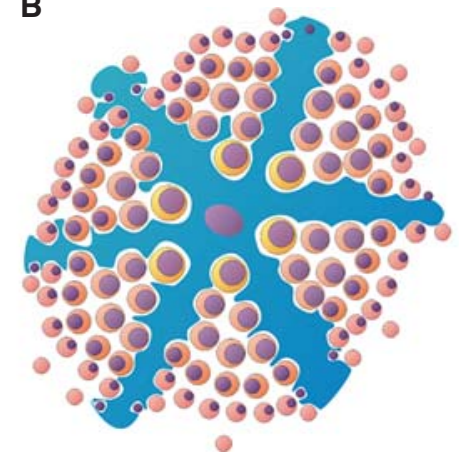

Pro-erythroblast Basophilic erythroblast Polychromatic erythroblast - Orthochromatic erythroblast - Erythrocyte

- Pyknotic nucleus

Central macrophage

Figure 5. The erythroblastic island. (A) Erythroblastic island in E13.5 fetal liver. The cytoplasmic extensions of the central macrophage (stained with the F4/80 antibody) (brown) are surrounding erythroid cells at various stages of differentiation. $(B)$ Schematic drawing of an erythroblastic island. 
and very little cytoplasmic actin is observed. Collectively, it can be concluded that MAEA is required for the organization of the erythroblastic island and for efficient enucleation of erythroblasts.

The role of other cell adhesion molecules and interactions with extracellular matrix proteins such as laminin and fibronectin is less clearly defined. Erythroblasts express $\alpha_{4}$ (Itga4)/ CD29/ $\beta_{1}$ integrin (Itgb1), and the CD242 (Icam4, LW blood group) counter-receptor. Macrophages express CD51 ( $\alpha_{\mathrm{v}}$ integrin, Itgav) and the vascular cell adhesion molecule 1 (Vcam1) counter-receptor. Perturbation of the integrin system can adversely affect erythroblastic island formation (Lee et al. 2006) and stress erythropoiesis (Scott et al. 2003), but the generic role of cell adhesion in tissue integrity and the considerable potential for redundancy preclude the assignment of specific functions to individual factors.

A role for signaling between erythroid cells has been most convincingly shown for death ligand/death receptor interactions. Erythroid cells express the CD95 (FAS) death receptor throughout differentiation. Only mature cells express the ligand CD95L (FASL), but these cells are insensitive to FAS signaling. In contrast, immature cells activate proapoptotic proteases in response to FASL exposure. The levels of the essential transcription factors TAL1 and GATA1 are reduced through cleavage by activated caspases, most notably by caspase 3 (CASP3) (De Maria et al. 1999; Zeuner et al. 2003; Ribeil et al. 2007). This will stop progression along the erythroid differentiation pathway and may induce cell death. A decreased survival rate of erythroid progenitor cells is a hallmark of many acquired and hereditary anemias. Patients with rheumatoid arthritis develop anemia in 50\% of cases, and treatment with a blocking antibody directed against the death receptor ligand TNF $\alpha$ improved the anemia and decreased the elevated numbers of apoptotic erythroid progenitors in the bone marrow (Papadaki et al. 2002). An increased rate of apoptosis is also observed in $\beta$-thalassemia patients. This results in a phenomenon known as ineffective erythropoiesis (Centis et al. 2000; Mathias et al. 2000;
Pootrakul et al. 2000; Papadaki et al. 2002). Up to $80 \%$ of erythroid progenitors may be lost because of apoptosis occurring at the polychromatic erythroblast stage (Mathias et al. 2000). The apoptotic erythroblasts are cleared very rapidly by macrophages. These cells are activated by increased interferon- $\gamma$ (IFNG) levels in approximately one-third of the patients (Wanachiwanawin et al. 1999), and this may contribute to the quantitative differences in ineffective erythropoiesis between different patients. In addition, many inflammatory diseases are accompanied by anemia, and in a mouse model, IFNG has been implicated in anemia of chronic disease by activating macrophages, reducing erythrocyte life span and inhibiting erythropoiesis (Libregts et al. 2011).

In normal erythropoiesis, expelled nuclei are phagocytosed very rapidly by the central macrophages. Once released, the nuclei contain very low levels of ATP and start to expose phosphatidylserine on their surface, because it requires energy to maintain phosphatidylserine exclusively localized to the inner leaflet of the cell membrane. Surface exposure of phosphatidylserine is an early event in apoptosis and serves as an "eat me" signal for apoptotic cells. This signal is also used for the engulfment of expelled nuclei by the macrophages (Yoshida et al. 2005).

\section{TRANSCRIPTIONAL REGULATION OF ERYTHROPOIESIS AND THE STEM CELL/ EARLY PROGENITOR COMPARTMENT}

A wide variety of transcription factors is involved in the establishment of hematopoietic cell lineages. For example, TAL1, a basic helixloop-helix transcription factor, and LMO2, an LIM-domain transcription factor, are critical for the onset of hematopoiesis because null embryos show complete absence of primitive and definitive hematopoiesis (Robb et al. 1995, 1996; Shivdasani et al. 1995; Porcher et al. 1996). The zinc-finger transcription factor GATA2 is also essential for the early stages of hematopoiesis. Primitive and definitive hematopoiesis is abrogated when the GATA2 gene is deleted, and it appears to play a role in the proliferation of the early precursors rather than in 
their differentiation (Tsai et al. 1994; Tsai and Orkin 1997). RUNX1 is crucial for the early stages of definitive hematopoiesis. In RUNX1null embryos, yolk sac hematopoiesis is normal but fetal liver hematopoiesis is absent (Okuda et al. 1996).

Once multipotent progenitors arise from the HSC and proliferate, the process of lineage restriction starts. The first step in this process involves restriction to either the myeloid or the lymphoid lineage. Transcription factors that are preferentially expressed in cells destined to one of those fates have been identified, but few have been extensively studied. PU.1, a member of the Ets family of transcription factors, is the best-studied transcription factor known to be involved in lineage restriction at this stage. PU.l's effect on lineage commitment is dependent on its expression level. A high level of expression leads to commitment to the myeloid lineage, whereas lower levels of expression lead to commitment to the lymphoid lineage (Scott et al. 1994; Nerlov and Graf 1998; Huang et al. 2007). Thus, owing to their role in the stem cell/ progenitor compartment, inactivation of these factors also affects erythropoiesis.

Because the number of transcription factors with identifiable functions specifically during erythropoiesis is too vast to allow a thorough discussion of each, we will focus on KLF1. This transcription factor is required for terminal erythroid differentiation and provides one of the best-studied examples of an erythroid transcriptional regulator. Expression of the KLF1 (formerly known as erythroid Krüppel-like factor [EKLF]) is largely restricted to the erythroid cell lineage (Southwood et al. 1996). KLF1 specifically binds the sequence $5^{\prime}$-CCACACCCT- $3^{\prime}$ (Miller and Bieker 1993). $\beta$-Thalassemia patients that carry mutations in the KLF1 binding site in the $\beta$-globin promoter display strongly reduced expression of $\beta$-globin (Orkin et al. 1984; Feng et al. 1994; Faustino et al. 1996). The role of KLF1 has been studied extensively in mice (Nuez et al. 1995; Perkins et al. 1995). Mice heterozygous for the KLF1 gene appear completely healthy. In the absence of KLF1, however, the fetuses develop a fatal anemia and die around E14. The primitive erythroid cells
Erythropoiesis: Development and Differentiation

function sufficiently for normal survival of the KLF1 knockout embryos up to $\sim$ E12. Embryonic globin gene expression is not influenced by the absence of KLF1, even though KLF1 normally binds these genes in vivo (Zhou et al. 2006). When the embryos switch to definitive erythropoiesis in the fetal liver, KLF1-null mutants rapidly develop anemia because of a deficit in $\beta$-globin expression. Remarkably, the number of CFU-E in the KLF1-null fetal livers is similar to those found in wild-type fetal livers, showing that KLF1 deficiency causes a very late erythroid defect (Nuez et al. 1995; Perkins et al. 1995). Furthermore, fetal liver-derived erythroid cells of $\mathrm{KLF}^{-/-}$fetuses have an abnormal morphology, and most of the cells retain a nucleus, indicating that the adult $\beta$-globin genes are not the only target genes of KLF1. Indeed, $\mathrm{KLF}^{-/-}$mice could not be rescued by expression of exogenous human $\gamma$-globin (Perkins et al. 2000). Genome-wide expression analyses of $\mathrm{KLF}^{-1-}$ erythroid cells showed that KLF1 activates many other erythroid-specific genes, including genes encoding proteins associated with the erythroid cell membrane, such as band 4.9/dematin. These proteins are important for the function and stability of the erythrocytes. In addition, KLF1 has a role in cell cycle regulation linked to the proliferation arrest required for terminal differentiation (Tallack et al. 2007). Thus, KLF1 is an activator of essential erythroid genes that are up-regulated during terminal erythroid differentiation.

The first reported loss-of-function mutations in human KLF1 were linked to the rare blood group $\operatorname{In}(\mathrm{Lu})$ (inhibitor of Lutheran antigen expression) and always occurred in the presence of a normal KLF1 allele. Gene expression profiling identified more than 650 putative KLF1 target genes, including the blood group antigens BCAM and CD44, which are suppressed in the $\operatorname{In}(\mathrm{Lu})$ individuals (Singleton et al. 2008). A study of a large Maltese pedigree concluded that haploinsufficiency for KLF1 causes HPFH. All carriers displayed high $\mathrm{HbF}$ levels, although with considerable variation (mean 8.4\%; range 3.3\%-19.5\%) (Borg et al. 2010). Part of this variability could be explained by SNP haplotypes at the BCL11Alocus (Menzel 
et al. 2007), which encodes a repressor of $\gamma$-globin expression (Sankaran et al. 2008). Importantly, KLF1 was shown to be a direct activator of BCL11A expression (Borg et al. 2010; Zhou et al. 2010). Therefore, attenuation of KLF1 activity could be a fruitful approach to raise $\mathrm{HbF}$ levels in patients with $\beta$-type hemoglobinopathies. Supporting this notion, a sickle cell anemia patient with KLF1 haploinsufficiency was reported recently (Gallienne et al. 2012). This patient displayed a high HbF level (20.3\%) and had a particularly mild disease phenotype. In contrast, missense mutations of critical residues in the DNA binding domain of KLF1 can have a dominant phenotype with severe consequences. Two unrelated patients with congenital dyserythropoietic anemia (CDA) carried a missense mutation (p.E325K) in the DNA-binding domain of KLF1. Although the patients displayed very high levels of $\mathrm{HbF}(31.6 \%$ and $44 \%)$, this mutation had a dominant effect that resulted in severe hemolytic anemia (Arnaud et al. 2010). Given the broad impact of KLF1 on erythroidspecific gene expression (Drissen et al. 2005; Pilon et al. 2008; Singleton et al. 2008; Borg et al. 2010), the array of human erythroid phenotypes associated with KLF1 mutations will likely be expanded as more cases are described in detail. This is illustrated by two recent studies reporting that zinc protoporphyria (Perseu et al. 2011) and increased HbA2 levels (Perseu et al. 2011) are linked to KLF1 mutations.

\section{CONCLUDING REMARKS}

In conclusion, much progress has been made in understanding the ontogeny, expansion, and terminal differentiation of erythroid cells, and future work will contribute to the ultimate goal of fully comprehending the molecular control of erythropoiesis at the systems level.

\section{ACKNOWLEDGMENTS}

We acknowledge support from the Landsteiner Society for Blood Research, Netherlands Institute for Regenerative Medicine FES subsidy, National Institutes of Health R37 DK54077, Netherlands Organization for Scientific Research
(NWO), and Netherlands Genomics Initiative (NGI).

\section{REFERENCES}

${ }^{*}$ Reference is also in this collection.

Adolfsson J, Mansson R, Buza-Vidas N, Hultquist A, Liuba K, Jensen CT, Bryder D, Yang L, Borge OJ, Thoren LA, et al. 2005. Identification of Flt $3^{+}$lymphomyeloid stem cells lacking erythro-megakaryocytic potential. Cell 121: 295-306.

Akashi K, Traver D, Miyamoto T, Weissman IL. 2000. A clonogenic common myeloid progenitor that gives rise to all myeloid lineages. Nature 404: 193-197.

Alvarez-Silva M, Belo-Diabangouaya P, Salaun J, DieterlenLievre F. 2003. Mouse placenta is a major hematopoietic organ. Development 130: 5437-5444.

Arnaud L, Saison C, Helias V, Lucien N, Steschenko D, Giarratana MC, Prehu C, Foliguet B, Montout L, de Brevern AG, et al. 2010. A dominant mutation in the gene encoding the erythroid transcription factor KLF1 causes a congenital dyserythropoietic anemia. Am J Hum Genet 87: 721-727.

* Arora N, Daley GQ. 2012. Pluripotent stem cells in research and treatment of hemoglobinopathies. Cold Spring Harb Perspect Med 2: a011841.

Bauer A, Tronche F, Wessely O, Kellendonk C, Reichardt HM, Steinlein P, Schutz G, Beug H. 1999. The glucocorticoid receptor is required for stress erythropoiesis. Genes Dev 13: 2996-3002.

Beaupain D, Martin C, Dieterlen-Lievre F. 1979. Are developmental hemoglobin changes related to the origin of stem cells and site of erythropoiesis? Blood 53: 212225.

Belaoussoff M, Farrington SM, Baron MH. 1998. Hematopoietic induction and respecification of A-P identity by visceral endoderm signaling in the mouse embryo. Development 125: 5009-5018.

Berry M, Grosveld F, Dillon N. 1992. A single point mutation is the cause of the Greek form of hereditary persistence of fetal haemoglobin. Nature 358: 499-502.

Bessis M. 1958. L'ilot erythroblastique, unite fonctionnelle de la moelle osseuse. Rev Hematol 13: 8-11.

Boisset JC, van Cappellen W, Andrieu-Soler C, Galjart N, Dzierzak E, Robin C. 2010. In vivo imaging of haematopoietic cells emerging from the mouse aortic endothelium. Nature 464: 116-120.

Borg J, Papadopoulos P, Georgitsi M, Gutierrez L, Grech G, Fanis P, Phylactides M, Verkerk AJ, van der Spek PJ, Scerri CA, et al. 2010. Haploinsufficiency for the erythroid transcription factor KLF1 causes hereditary persistence of fetal hemoglobin. Nat Genet 42: 801-805.

Boyer SH, Belding TK, Margolet L, Noyes AN. 1975. Fetal hemoglobin restriction to a few erythrocytes ( $F$ cells) in normal human adults. Science 188: 361-363.

* Bunn HF. 2013. Erythropoietin. Cold Spring Harb Perspect Med doi: 10.1101/cshperspect.a011619.

Buza-Vidas N, Luc S, Jacobsen SE. 2007. Delineation of the earliest lineage commitment steps of haematopoietic 
stem cells: New developments, controversies and major challenges. Curr Opin Hematol 14: 315-321.

Carotta S, Pilat S, Mairhofer A, Schmidt U, Dolznig H, Steinlein P, Beug H. 2004. Directed differentiation and mass cultivation of pure erythroid progenitors from mouse embryonic stem cells. Blood 104: 1873-1880.

Centis F, Tabellini L, Lucarelli G, Buffi O, Tonucci P, Persini B, Annibali M, Emiliani R, Iliescu A, Rapa S, et al. 2000. The importance of erythroid expansion in determining the extent of apoptosis in erythroid precursors in patients with $\beta$-thalassemia major. Blood 96: 36243629.

Chen MJ, Yokomizo T, Zeigler BM, Dzierzak E, Speck NA. 2009. Runx1 is required for the endothelial to haematopoietic cell transition but not thereafter. Nature 457: 887-891.

Ciau-Uitz A, Walmsley M, Patient R. 2000. Distinct origins of adult and embryonic blood in Xenopus. Cell 102: 787-796.

Corbel C, Salaun J, Belo-Diabangouaya P, Dieterlen-Lievre F. 2007. Hematopoietic potential of the pre-fusion allantois. Dev Biol 301: 478-488.

Cormier F, Dieterlen-Lievre F. 1988. The wall of the chick embryo aorta harbours M-CFC, G-CFC, GM-CFC and BFU-E. Development 102: 279-285.

Cumano A, Dieterlen-Lievre F, Godin I. 1996. Lymphoid potential, probed before circulation in mouse, is restricted to caudal intraembryonic splanchnopleura. Cell 86: 907-916.

de Bruijn MF, Speck NA, Peeters MC, Dzierzak E. 2000. Definitive hematopoietic stem cells first develop within the major arterial regions of the mouse embryo. $E M B O J$ 19: $2465-2474$.

de Bruijn MF, Ma X, Robin C, Ottersbach K, Sanchez MJ, Dzierzak E. 2002. Hematopoietic stem cells localize to the endothelial cell layer in the midgestation mouse aorta. Immunity 16: 673-683.

De Maria R, Zeuner A, Eramo A, Domenichelli C, Bonci D, Grignani F, Srinivasula SM, Alnemri ES, Testa U, Peschle C. 1999. Negative regulation of erythropoiesis by caspase-mediated cleavage of GATA-1. Nature 401: 489-493.

Dieterlen-Lievre F. 1975. On the origin of haemopoietic stem cells in the avian embryo: An experimental approach. J Embryol Exp Morphol 33: 607-619.

Dieterlen-Lievre F, Martin C. 1981. Diffuse intraembryonic hemopoiesis in normal and chimeric avian development. Dev Biol 88: 180-191.

Dillon N, Grosveld F. 1991. Human $\gamma$-globin genes silenced independently of other genes in the $\beta$-globin locus. $\mathrm{Na}$ ture 350: 252-254.

Dolznig H, Boulme F, Stangl K, Deiner EM, Mikulits W, Beug H, Mullner EW. 2001. Establishment of normal, terminally differentiating mouse erythroid progenitors: Molecular characterization by cDNA arrays. FASEB J 15: 1442-1444.

Douay L, Andreu G. 2007. Ex vivo production of human red blood cells from hematopoietic stem cells: What is the future in transfusion? Transfus Med Rev 21: 91-100.

Downs KM. 1998. The murine allantois. Curr Top Dev Biol 39: $1-33$.
Erythropoiesis: Development and Differentiation

Drissen R, von Lindern M, Kolbus A, Driegen S, Steinlein P, Beug H, Grosveld F, Philipsen S. 2005. The erythroid phenotype of EKLF-null mice: Defects in hemoglobin metabolism and membrane stability. Mol Cell Biol 25: 5205-5214.

Dzierzak E, Speck NA. 2008. Of lineage and legacy: The development of mammalian hematopoietic stem cells. Nat Immunol 9: 129-136.

Ema H, Nakauchi H. 2000. Expansion of hematopoietic stem cells in the developing liver of a mouse embryo. Blood 95: 2284-2288.

Faustino P, Lavinha J, Marini MG, Moi P. 1996. $\beta$-Thalassemia mutation at $-90 \mathrm{C} \rightarrow \mathrm{T}$ impairs the interaction of the proximal CACCC box with both erythroid and nonerythroid factors. Blood 88: 3248-3249.

Feng WC, Southwood CM, Bieker JJ. 1994. Analyses of $\beta$ thalassemia mutant DNA interactions with erythroid Kruppel-like factor (EKLF), an erythroid cell-specific transcription factor. J Biol Chem 269: 1493-1500.

Ferreira R, Ohneda K, Yamamoto M, Philipsen S. 2005. GATA1 function, a paradigm for transcription factors in hematopoiesis. Mol Cell Biol 25: 1215-1227.

Fibach E, Manor D, Oppenheim A, Rachmilewitz EA. 1989. Proliferation and maturation of human erythroid progenitors in liquid culture. Blood 73: 100-103.

Fraser ST, Isern J, Baron MH. 2007. Maturation and enucleation of primitive erythroblasts during mouse embryogenesis is accompanied by changes in cell-surface antigen expression. Blood 109: 343-352.

Gallienne AE, Dreau HM, Schuh A, Old J, Henderson S. 2012. Ten novel mutations in the erythroid transcription factor KLF1 gene associated with increased fetal hemoglobin levels in adults. Haematologica 97: 340-343.

Gekas C, Dieterlen-Lievre F, Orkin SH, Mikkola HK. 2005. The placenta is a niche for hematopoietic stem cells. Dev Cell 8: $365-375$.

Giarratana MC, Kobari L, Lapillonne H, Chalmers D, Kiger L, Cynober T, Marden MC, Wajcman $\mathrm{H}$, Douay L. 2005. Ex vivo generation of fully mature human red blood cells from hematopoietic stem cells. Nat Biotechnol 23: 69-74.

Godin I, Dieterlen-Lievre F, Cumano A. 1995. Emergence of multipotent hemopoietic cells in the yolk sac and paraaortic splanchnopleura in mouse embryos, beginning at 8.5 days postcoitus. Proc Natl Acad Sci 92: 773-777.

Huang G, Zhang P, Hirai H, Elf S, Yan X, Chen Z, Koschmieder S, Okuno Y, Dayaram T, Growney JD, et al. 2007. PU.1 is a major downstream target of AML1 (RUNX1) in adult mouse hematopoiesis. Nat Genet 40: 51-60.

Huber TL, Kouskoff V, Fehling HJ, Palis J, Keller G. 2004. Haemangioblast commitment is initiated in the primitive streak of the mouse embryo. Nature 432: 625-630.

Kinder SJ, Tsang TE, Quinlan GA, Hadjantonakis AK, Nagy A, Tam PP. 1999. The orderly allocation of mesodermal cells to the extraembryonic structures and the anteroposterior axis during gastrulation of the mouse embryo. Development 126: 4691-4701.

Kondo M, Weissman IL, Akashi K. 1997. Identification of clonogenic common lymphoid progenitors in mouse bone marrow. Cell 91: 661-672. 
Lawson KA, Meneses JJ, Pedersen RA. 1991. Clonal analysis of epiblast fate during germ layer formation in the mouse embryo. Development 113: 891-911.

Lee G, Lo A, Short SA, Mankelow TJ, Spring F, Parsons SF, Yazdanbakhsh K, Mohandas N, Anstee DJ, Chasis JA. 2006. Targeted gene deletion demonstrates that the cell adhesion molecule ICAM-4 is critical for erythroblastic island formation. Blood 108: 2064-2071.

Lenox LE, Perry JM, Paulson RF. 2005. BMP4 and Madh5 regulate the erythroid response to acute anemia. Blood 105: $2741-2748$.

Libregts SF, Gutierrez L, de Bruin AM, Wensveen FM, Papadopoulos P, van Ijcken W, Ozgur Z, Philipsen S, Nolte MA. 2011. Chronic IFN- $\gamma$ production in mice induces anemia by reducing erythrocyte life span and inhibiting erythropoiesis through an IRF-1/PU.1 axis. Blood 118: 2578-2588.

Lin CS, Lim SK, D’Agati V, Costantini F. 1996. Differential effects of an erythropoietin receptor gene disruption on primitive and definitive erythropoiesis. Genes Dev 10: $154-164$.

Liu Y, Pop R, Sadegh C, Brugnara C, Haase VH, Socolovsky M. 2006. Suppression of Fas-FasL coexpression by erythropoietin mediates erythroblast expansion during the erythropoietic stress response in vivo. Blood 108: 123-133.

Lux CT, Yoshimoto M, McGrath K, Conway SJ, Palis J, Yoder MC. 2007. All primitive and definitive hematopoietic progenitor cells emerging prior to E10 in the mouse embryo are products of the yolk sac. Blood 111: 3435 3438.

Manz MG, Miyamoto T, Akashi K, Weissman IL. 2002. Prospective isolation of human clonogenic common myeloid progenitors. Proc Natl Acad Sci 99: 11872-11877.

Martin C, Beaupain D, Dieterlen-Lievre F. 1978. Developmental relationships between vitelline and intra-embryonic haemopoiesis studied in avian "yolk sac chimaeras." Cell Differ 7: 115-130.

Mathias LA, Fisher TC, Zeng L, Meiselman HJ, Weinberg KI, Hiti AL, Malik P. 2000. Ineffective erythropoiesis in $\beta$ thalassemia major is due to apoptosis at the polychromatophilic normoblast stage. Exp Hematol 28: $1343-$ 1353.

McGrath KE, Palis J. 2005. Hematopoiesis in the yolk sac: More than meets the eye. Exp Hematol 33: 1021-1028.

Medvinsky A, Dzierzak E. 1996. Definitive hematopoiesis is autonomously initiated by the AGM region. Cell 86: 897-906.

Menon MP, Karur V, Bogacheva O, Bogachev O, Cuetara B, Wojchowski DM. 2006. Signals for stress erythropoiesis are integrated via an erythropoietin receptor-phosphotyrosine-343-Stat5 axis. J Clin Invest 116: 683-694.

Menzel S, Garner C, Gut I, Matsuda F, Yamaguchi M, Heath S, Foglio M, Zelenika D, Boland A, Rooks H, et al. 2007. A QTL influencing F cell production maps to a gene encoding a zinc-finger protein on chromosome 2p15. Nat Genet 39: 1197-1199.

Migliaccio AR, Campisi S, Migliaccio G. 2001. Standardization of progenitor cell assay for cord blood banking. Ann Ist Super Sanita 37: 595-600.
Migliaccio G, Di Pietro R, di Giacomo V, Di Baldassarre A, Migliaccio AR, Maccioni L, Galanello R, Papayannopoulou T. 2002. In vitro mass production of human erythroid cells from the blood of normal donors and of thalassemic patients. Blood Cells Mol Dis 28: 169-180.

Miller IJ, Bieker JJ. 1993. A novel, erythroid cell-specific murine transcription factor that binds to the CACCC element and is related to the Kruppel family of nuclear proteins. Mol Cell Biol 13: 2776-2786.

Moore MA, Metcalf D. 1970. Ontogeny of the haemopoietic system: Yolk sac origin of in vivo and in vitro colony forming cells in the developing mouse embryo. $\mathrm{Br} \mathrm{J} \mathrm{Hae-}$ matol 18: 279-296.

Muller AM, Medvinsky A, Strouboulis J, Grosveld F, Dzierzak E. 1994. Development of hematopoietic stem cell activity in the mouse embryo. Immunity 1: 291-301.

Murray P. 1932. The development in vitro of the blood of the early chick embryo. Proc Roy Soc London 11: 497-521.

Neildez-Nguyen TM, Wajcman H, Marden MC, Bensidhoum M, Moncollin V, Giarratana MC, Kobari L, Thierry D, Douay L. 2002. Human erythroid cells produced ex vivo at large scale differentiate into red blood cells in vivo. Nat Biotechnol 20: 467-472.

Nerlov C, Graf T. 1998. PU.1 induces myeloid lineage commitment in multipotent hematopoietic progenitors. Genes Dev 12: 2403-2412.

North TE, de Bruijn MF, Stacy T, Talebian L, Lind E, Robin C, Binder M, Dzierzak E, Speck NA. 2002. Runx1 expression marks long-term repopulating hematopoietic stem cells in the midgestation mouse embryo. Immunity 16: 661-672.

Nuez B, Michalovich D, Bygrave A, Ploemacher R, Grosveld F. 1995. Defective haematopoiesis in fetal liver resulting from inactivation of the EKLF gene. Nature 375: 316-318.

Okuda T, van Deursen J, Hiebert SW, Grosveld G, Downing JR. 1996. AML1, the target of multiple chromosomal translocations in human leukemia, is essential for normal fetal liver hematopoiesis. Cell 84: 321-330.

Olivier EN, Qiu C, Velho M, Hirsch RE, Bouhassira EE. 2006. Large-scale production of embryonic red blood cells from human embryonic stem cells. Exp Hematol 34: $1635-1642$.

Orkin SH, Antonarakis SE, Kazazian HH Jr. 1984. Base substitution at position -88 in a $\beta$-thalassemic globin gene. Further evidence for the role of distal promoter element ACACCC. J Biol Chem 259: 8679-8681.

Ottersbach K, Dzierzak E. 2005. The murine placenta contains hematopoietic stem cells within the vascular labyrinth region. Dev Cell 8: 377-387.

Papadaki HA, Kritikos HD, Valatas V, Boumpas DT, Eliopoulos GD. 2002. Anemia of chronic disease in rheumatoid arthritis is associated with increased apoptosis of bone marrow erythroid cells: Improvement following anti-tumor necrosis factor- $\alpha$ antibody therapy. Blood 100: 474-482.

Papayannopoulou T, Brice M, Stamatoyannopoulos G. 1977. Hemoglobin F synthesis in vitro: Evidence for control at the level of primitive erythroid stem cells. Proc Natl Acad Sci 74: 2923-2927. 
Erythropoiesis: Development and Differentiation

Park C, Ma YD, Choi K. 2005. Evidence for the hemangioblast. Exp Hematol 33: 965-970.

Perkins AC, Sharpe AH, Orkin SH. 1995. Lethal $\beta$-thalassaemia in mice lacking the erythroid CACCC-transcription factor EKLF. Nature 375: 318-322.

Perkins AC, Peterson KR, Stamatoyannopoulos G, Witkowska HE, Orkin SH. 2000. Fetal expression of a human A $\gamma$ globin transgene rescues globin chain imbalance but not hemolysis in EKLF null mouse embryos. Blood 95: $1827-1833$.

Perseu L, Satta S, Moi P, Demartis FR, Manunza L, Sollaino MC, Barella S, Cao A, Galanello R. 2011. KLF1 gene mutations cause borderline $\operatorname{HbA}(2)$. Blood 118: 4454-4458.

Peterson KR, Li QL, Clegg CH, Furukawa T, Navas PA, Norton EJ, Kimbrough TG, Stamatoyannopoulos G. 1995. Use of yeast artificial chromosomes (YACs) in studies of mammalian development: Production of $\beta$-globin locus YAC mice carrying human globin developmental mutants. Proc Natl Acad Sci 92: 5655-5659.

Pilat S, Carotta S, Schiedlmeier B, Kamino K, Mairhofer A, Will E, Modlich U, Steinlein P, Ostertag W, Baum C, et al. 2005. HOXB4 enforces equivalent fates of ES-cell-derived and adult hematopoietic cells. Proc Natl Acad Sci 102: 12101-12106.

Pilon AM, Arcasoy MO, Dressman HK, Vayda SE, Maksimova YD, Sangerman JI, Gallagher PG, Bodine DM. 2008. Failure of terminal erythroid differentiation in EKLF-deficient mice is associated with cell cycle perturbation and reduced expression of E2F2. Mol Cell Biol 28: 7394-7401.

Pootrakul P, Sirankapracha P, Hemsorach S, Moungsub W, Kumbunlue R, Piangitjagum A, Wasi P, Ma L, Schrier SL. 2000. A correlation of erythrokinetics, ineffective erythropoiesis, and erythroid precursor apoptosis in Thai patients with thalassemia. Blood 96: 2606-2612.

Porcher C, Swat W, Rockwell K, Fujiwara Y, Alt FW, Orkin SH. 1996. The T cell leukemia oncoprotein SCL/ tal-1 is essential for development of all hematopoietic lineages. Cell 86: 47-57.

Ribeil JA, Zermati Y, Vandekerckhove J, Cathelin S, Kersual J, Dussiot M, Coulon S, Moura IC, Zeuner A, KirkegaardSorensen T, et al. 2007. Hsp70 regulates erythropoiesis by preventing caspase-3-mediated cleavage of GATA-1. $\mathrm{Na}$ ture 445: 102-105.

Robb L, Lyons I, Li R, Hartley L, Kontgen F, Harvey RP, Metcalf D, Begley CG. 1995. Absence of yolk sac hematopoiesis from mice with a targeted disruption of the $s c l$ gene. Proc Natl Acad Sci 92: 7075-7079.

Robb L, Elwood NJ, Elefanty AG, Kontgen F, Li R, Barnett LD, Begley CG. 1996. The scl gene product is required for the generation of all hematopoietic lineages in the adult mouse. EMBO J 15: 4123-4129.

Russell ES, Bernstein SE. 1966. Blood and blood formation. In Biology of the laboratory mouse (ed. Green EL), pp. 351-372. McGraw-Hill, New York.

Sabin F. 1920. Studies on the origin of blood vessels and of red blood corpuscles as seen in the living blastoderm of chicks during the second day of incubation, Vol. 9, p. 214. Carnegie Institute of Washington, Washington, DC.
* Sankaran VG, Orkin SH. 2013. The switch from fetal to adult hemoglobin. Cold Spring Harb Perspect Med 3: a011643.

Sankaran VG, Menne TF, Xu J, Akie TE, Lettre G, Van Handel B, Mikkola HK, Hirschhorn JN, Cantor AB, Orkin SH. 2008. Human fetal hemoglobin expression is regulated by the developmental stage-specific repressor BCL11A. Science 322: 1839-1842.

Scott EW, Simon MC, Anastasi J, Singh H. 1994. Requirement of transcription factor PU.1 in the development of multiple hematopoietic lineages. Science 265: 15731577.

Scott LM, Priestley GV, Papayannopoulou T. 2003. Deletion of $\alpha 4$ integrins from adult hematopoietic cells reveals roles in homeostasis, regeneration, and homing. Mol Cell Biol 23: 9349-9360.

Shalaby F, Rossant J, Yamaguchi TP, Gertsenstein M, Wu XF, Breitman ML, Schuh AC. 1995. Failure of blood-island formation and vasculogenesis in Flk-1-deficient mice. Nature 376: 62-66.

Shivdasani RA, Mayer EL, Orkin SH. 1995. Absence of blood formation in mice lacking the T-cell leukaemia oncoprotein tal-1/SCL. Nature 373: 432-434.

Singleton BK, Burton NM, Green C, Brady RL, Anstee DJ 2008. Mutations in EKLF/KLF1 form the molecular basis of the rare blood group $\operatorname{In}(\mathrm{Lu})$ phenotype. Blood 112: 2081-2088.

Socolovsky M. 2007. Molecular insights into stress erythropoiesis. Curr Opin Hematol 14: 215-224.

Socolovsky M, Fallon AE, Wang S, Brugnara C, Lodish HF. 1999. Fetal anemia and apoptosis of red cell progenitors in Stat $5 \mathrm{a}^{-/-} 5 \mathrm{~b}^{-/-}$mice: A direct role for Stat5 in Bcl$\mathrm{X}(\mathrm{L})$ induction. Cell 98: 181-191.

Socolovsky M, Nam H, Fleming MD, Haase VH, Brugnara C, Lodish HF. 2001. Ineffective erythropoiesis in Stat $5 \mathrm{a}^{-/-} \mathrm{b}^{-/-}$mice due to decreased survival of early erythroblasts. Blood 98: 3261-3273.

Soni S, Bala S, Gwynn B, Sahr KE, Peters LL, Hanspal M. 2006. Absence of erythroblast macrophage protein (Emp) leads to failure of erythroblast nuclear extrusion. J Biol Chem 281: 20181-20189.

Southwood CM, Downs KM, Bieker JJ. 1996. Erythroid Kruppel-like factor exhibits an early and sequentially localized pattern of expression during mammalian erythroid ontogeny. Dev Dyn 206: 248-259.

Stamatoyannopoulos G. 2005. Control of globin gene expression during development and erythroid differentiation. Exp Hematol 33: 259-271.

Strouboulis J, Dillon N, Grosveld F. 1992. Developmental regulation of a complete $70-\mathrm{kb}$ human $\beta$-globin locus in transgenic mice. Genes Dev 6: 1857-1864.

Tallack MR, Keys JR, Perkins AC. 2007. Erythroid Kruppellike factor regulates the G1 cyclin dependent kinase inhibitor $\mathrm{p} 18^{\mathrm{INK} 4 \mathrm{c}}$. J Mol Biol 369: 313-321.

Tavian M, Peault B. 2005. Embryonic development of the human hematopoietic system. Int J Dev Biol 49: 243-250.

Tavian M, Hallais MF, Peault B. 1999. Emergence of intraembryonic hematopoietic precursors in the pre-liver human embryo. Development 126: 793-803.

Tsai FY, Orkin SH. 1997. Transcription factor GATA-2 is required for proliferation/survival of early hematopoietic 
E. Dzierzak and S. Philipsen

cells and mast cell formation, but not for erythroid and myeloid terminal differentiation. Blood 89: 3636-3643.

Tsai FY, Keller G, Kuo FC, Weiss M, Chen J, Rosenblatt M, Alt FW, Orkin SH. 1994. An early haematopoietic defect in mice lacking the transcription factor GATA-2. Nature 371: 221-226.

Turpen JB, Knudson CM. 1982. Ontogeny of hematopoietic cells in Rana pipiens: Precursor cell migration during embryogenesis. Dev Biol 89: 138-151.

Ueno H, Weissman IL. 2006. Clonal analysis of mouse development reveals a polyclonal origin for yolk sac blood islands. Dev Cell 11: 519-533.

van den Akker E, Satchwell TJ, Pellegrin S, Daniels G Toye AM. 2010. The majority of the in vitro erythroid expansion potential resides in CD34- cells, outweighing the contribution of $\mathrm{CD} 34^{+}$cells and significantly increasing the erythroblast yield from peripheral blood samples. Haematologica 95: 1594-1598.

Wanachiwanawin W, Wiener E, Siripanyaphinyo U, Chinprasertsuk S, Mawas F, Fucharoen S, Wickramasinghe SN, Pootrakul P, Visudhiphan S. 1999. Serum levels of tumor necrosis factor- $\alpha$, interleukin- 1 , and interferon- $\gamma$ in $\beta^{0}$ thalassemia/HbE and their clinical significance. J Interferon Cytokine Res 19: 105-111.

Wood HB, May G, Healy L, Enver T, Morriss-Kay GM. 1997. CD34 expression patterns during early mouse development are related to modes of blood vessel formation and reveal additional sites of hematopoiesis. Blood 90: 23002311.
Wu H, Klingmuller U, Besmer P, Lodish HF. 1995. Interaction of the erythropoietin and stem-cell-factor receptors. Nature 377: 242-246.

Yokomizo T, Yamada-Inagawa T, Yzaguirre AD, Chen MJ, Speck NA, Dzierzak E. 2012. Whole-mount three-dimensional imaging of internally localized immunostained cells within mouse embryos. Nat Protoc 7: 421431.

Yoshida H, Kawane K, Koike M, Mori Y, Uchiyama Y, Nagata S. 2005. Phosphatidylserine-dependent engulfment by macrophages of nuclei from erythroid precursor cells. Nature 437: 754-758.

Zeigler BM, Sugiyama D, Chen M, Guo Y, Downs KM, Speck NA. 2006. The allantois and chorion, when isolated before circulation or chorio-allantoic fusion, have hematopoietic potential. Development 133: 4183-4192.

Zeuner A, Eramo A, Testa U, Felli N, Pelosi E, Mariani G, Srinivasula SM, Alnemri ES, Condorelli G, Peschle C, et al. 2003. Control of erythroid cell production via caspasemediated cleavage of transcription factor SCL/Tal-1. Cell Death Differ 10: 905-913.

Zhou D, Pawlik KM, Ren J, Sun CW, Townes TM. 2006. Differential binding of erythroid Krupple-like factor to embryonic/fetal globin gene promoters during development. J Biol Chem 281: 16052-16057.

Zhou D, Liu K, Sun CW, Pawlik KM, Townes TM. 2010 KLF1 regulates BCL11A expression and $\gamma$ - to $\beta$-globin gene switching. Nat Genet 42: 742-744. 


\title{
$\&_{\mathrm{CSH}}^{\infty} \&$ Cold Spring Harbor

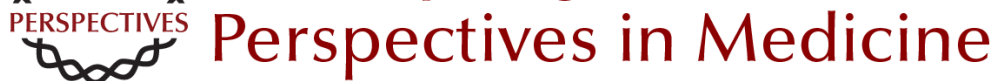

\section{Erythropoiesis: Development and Differentiation}

\author{
Elaine Dzierzak and Sjaak Philipsen \\ Cold Spring Harb Perspect Med 2013; doi: 10.1101/cshperspect.a011601
}

Subject Collection Hemoglobin and Its Diseases

The Natural History of Sickle Cell Disease Graham R. Serjeant

Current Management of Sickle Cell Anemia Patrick T. McGann, Alecia C. Nero and Russell E. Ware

Cell-Free Hemoglobin and Its Scavenger Proteins: New Disease Models Leading the Way to Targeted Therapies Dominik J. Schaer and Paul W. Buehler

Clinical Manifestations of $\alpha$-Thalassemia Elliott P. Vichinsky

Erythroid Heme Biosynthesis and Its Disorders Harry A. Dailey and Peter N. Meissner

Hemoglobin Variants: Biochemical Properties and

Clinical Correlates Christopher S. Thom, Claire F. Dickson, David A. Gell, et al.

The Prevention of Thalassemia Antonio Cao and Yuet Wai Kan

The Switch from Fetal to Adult Hemoglobin Vijay G. Sankaran and Stuart H. Orkin

\author{
Transcriptional Mechanisms Underlying \\ Hemoglobin Synthesis \\ Koichi R. Katsumura, Andrew W. DeVilbiss, \\ Nathaniel J. Pope, et al.
}

Iron Deficiency Anemia: A Common and Curable Disease Jeffery L. Miller

Management of the Thalassemias Nancy F. Olivieri and Gary M. Brittenham

The Molecular Basis of $\beta$-Thalassemia Swee Lay Thein

Erythropoiesis: Development and Differentiation Elaine Dzierzak and Sjaak Philipsen

Erythropoietin

H. Franklin Bunn

Classification of the Disorders of Hemoglobin Bernard G. Forget and H. Franklin Bunn

The Molecular Basis of $\alpha$-Thalassemia Douglas R. Higgs

For additional articles in this collection, see http://perspectivesinmedicine.cshlp.org/cgi/collection/ 